\title{
The Dark Life of Women in India
}

\author{
B. Pooja Sudharma ${ }^{1}$, N.B. Chandrakala ${ }^{2}$ \\ ${ }^{1}$ Research Scholar, Dept, of Law, Sri Padmavathi Mahila Visvavidyalayam (Women's University), Tirupati, \\ Andhra Pradesh. \\ ${ }^{2}$ Professor, Dept. of Law, Sri Padmavathi Mahila Visvavidyalayam (Women's University), Tirupati, Andhra \\ Pradesh.
}

\begin{abstract}
Can we imagine a day without women? Particularly in the countries like India, a day without women is a day without love, care, food and everything. India is the only country where the variety of goddess worshipped and India is the one of the developing countries where women have lesser value than men and living with the insecurities. From the ancient period to till now, women played a very prominent role in each and every field, but the discrimination against women is still exists. The slogan of equal rights for women is reminding us that the women are still not equal to men. It is common that any person can have problems during their lifetime but the sad reality is that, the women are facing problems even before their birth in the form of foeticides. Beginning with that, in each and every stage of life, women are facing all kinds of discrimination and subjected for exploitation of their rights. This paper details the kinds of offences that are happening against women along with the related provisions made by our government and how they are failed implement the provisions and to achieve the objects they are made for. This paper also contains the suggestions to improve the status of women in India.
\end{abstract}

Key Words: Indian Women, Women Legislations, Dark side of women life, Women Freedom.

\section{INTRODUCTION}

\section{"Freedom cannot be achieved unless women have been emancipated from all kinds of oppression." - Nelson Mandela}

This quote by the great philanthropist Nelson Mandela describes that the women need all kinds of liberty, independence and self-determination to achieve anything in the society. But the slogan of equal rights to women is reminding us that the women are not equal to men till today. We cannot imagine a day without women, particularly in a country like India, a day without women is a day without love, care, food and everything. India is the only country where the variety of goddess worshipped and India is one of the developing countries where women have lesser value than men. From the ancient period to till now, women played very prominent roles as queens, freedom fighters and stepped into each and every field in this modern era without neglecting their role as house makers, but still the discrimination against women is prevailing in our country.

\section{REVIEW OF LITERATURE}

In the current article, the researcher used both theoretical and empirical type of study. The theoretical work dealt with the literature relating to crimes against women. To meet the requirements of the study, the library method of research to scan the available literature in the forms of books, reported case laws, reports of the committees and commissions of the government and international documents such as conventions/recommendations/guidelines related to protection and welfare of women has been studied. Apart from this, Acts, rules of concerned legislations and various judgments of different courts such as the Supreme Court of India and various High Courts of India have also been taken into consideration. The related data is also collected from magazines, articles and newspapers as well. We have to mention that the use of Internet had a substantial effect on this article without which this would have been impossible because with the advancement of technology now most of the information can be accessed online. We have tried our level best to 


\section{International Advanced Research Journal in Science, Engineering and Technology}

Vol. 8, Issue 8, August 2021

DOI: 10.17148/IARJSET.2021.8847

collect data from the reliable websites of the government and of international organizations and all sources of information, digital or otherwise, have been cited in footnotes to the main text. But as websites and URLs being transient in nature, sometimes links might have lapsed so the footnotes only tell of those sites that existed at the time of writing along with the date when they were accessed.

\section{RESEARCH METHODOLOGY}

To analyse this article, a complete theriotical study is not sufficient and cannot be very beneficial. We conducted an empirical study in order to find out the deep roots of the actual problem. To collect the required data for the research which is the important step in this article, we referred many websites and journals. To carry out empirical study data was collected from various strata of society, which are involved in any way with this problem. After the data was collected, it was arranged in order to bring the article in a proper format.

\section{ANALYSIS}

The hard life of women in India begins even before the birth in the form of foeticides. The child sex ratio between the ages 0-6 is just 918 girls per every 1000 boys as per the census conducted in $2011 .^{1}$ This shows that sex selective abortions are still taking place though we have PNDT enactment ${ }^{2}$ which enacted to ban the gender screening tests and female foeticides and to punish the offenders. But absolutely nil reports and cases are filing against it because the victim women may not dare to complaint or the victim herself willing to have a male baby to avoid the insults from the maternal house. As per a story from our puranas, the son will protect the father and ancestors from going to 'Punnama Narakam' (hell) after the death. To avoid that hell which is only imaginary, some of the people are not letting the female babies to see this real world. In other cases, parents who are expecting the male baby and unable to detect the gender before birth, abandoning the female babies in dustbins and other places leaving them to the death.

There are many cases reporting regarding the abandonment of female babies in dustbins and in isolated places. In most of these cases, the baby dies before anyone finds and call for the child help. As per the UNICEF reports, India is the home for nearly 31 million orphaned children. It is reported that majority of those children are girls. These numbers are only based on the reported cases. Section $317^{3}$ of the Indian Penal Code, 1860 says that the child abandonment is the punishable offence. It is to be noted that there are very few cases filed under this section. And the most important thing is majority people do not aware of this section.

After the birth, the major problem that the girl child's facing is inequal treatment. It is deeply rooted feeling in the Indian parents that their savings will be for girl child's wedding and boy child's education because the boy viewed as the asset and bread winner of the family with an obligation to take care of the parents at their old age and the girl treated as the burden and liability. After the marriage, the girl will have to take care of her maternal parents. So, the parents treat the girl babies with a bit lesser concern. The Constitution of India under Article 14 makes every citizen equal and provides equal rights but this kind of inequal treatment officially allowed in our society. Another important and undiscussed problem is imposing restrictions on girls. Starting from the way of dressing to the walking and laughing style, there are numerous restrictions imposed on the girls in the Indian society. In some corners of the country, the girls do not have the

\footnotetext{
${ }^{1}$ Censusindia.gov.in

${ }^{2}$ Pre-natal Diagnostic Techniques (Regulation and Prevention of Misuse) Act, 1994

${ }^{3}$ Exposure and abandonment of child under twelve years, by parent or person having care of it (C) IARJSET 


\section{International Advanced Research Journal in Science, Engineering and Technology}

Vol. 8, Issue 8, August 2021

DOI: 10.17148/IARJSET.2021.8847

freedom to choose their career. There are very few numbers of parents that supports their girl child to the extra-curricular activities and sports. It builds an inferiority complex in the young girl's minds which leads to compromise their interests. Another threat to the women is malnutrition. Most of us not known that Malnutrition is a serious problem but it leads to serious health issues. As per the Global Hunger Index report, India ranked $100^{\text {th }}$ out of 112 countries. Due to economic inequalities and low social status of the parents, many girls and women suffers malnutrition. Another reason for this problem is the tradition in India which says women eat last and least. It is inevitable that an undernourished mother gives birth to an undernourished baby. Though the government made some schemes to provide nutritional food to the women during their pregnancy and post partem period but it is not sufficient to curb the malnutrition problem in India.

Kidnapping, trafficking and forced prostitution are very common in India. Indian Penal Code made sufficient provisions and punishments for the above said offences under various sections. But these crimes are always high in number. The offenders' targets economically backword women in the name of employment especially in other countries forces them to enter the prostitution field. Our system shall monitor the employees working in other states regularly and to know their well-being from time to time. The government shall create a toll-free number for the employees working in other countries to make an easy way to contact for help in the case of emergency

Child Marriages is the biggest threat to the girls in India. It is an open secret that the child marriages are taking place till today in some remote areas of the country. To avoid this evil custom, the girl child shall be well educated and get aware of the health and psychological consequences of the early marriage. The prohibition Child Marriage Act, 2006 made the punishments stringent but still the child marriages are taking place due to illiteracy, lack of awareness and due to social status.

Eve teasing and stalking is a very common offence against women in India. The word eve teasing is not officially recognised in Indian laws and so no specific law for eve teasing in India. Eve teasing cases are filing under section $294^{4}$ of Indian Penal Code, 1860 which is not sufficient to provide relief for the eve teasing. In the latest amendment to IPC, under section 354D stalking is well defined and provided punishments for the offenders.

In India, we have an enactment named "Sexual Harassment of Women at Workplace (Prevention, Prohibition and Redressal) Act, 2013 for the protection of working women from their superiors. But the harassment is still prevailing till today. This is one of the major reason that the family members do not send their women to work.

Acid attack is a crime of recent origin and increasing every year. This increasing number has to be treated as wake-up call to the law enforcing departments. The first ever acid attack in India happened in 2005, then we have amended our penal code and introduced a new section 326A that provides punishment for the offenders of acid attack. But the acid attacks are not stopped. The government shall impose restrictions on the sale of acid and other such substances. Though the victims survived from the attack, the scars that they experience will mentally slaughter them each day of life.

In India honour killings are as common as love marriages. It is the murder of an individual by the family members to protect the dignity of their family. In this modern era also, women don't have the right to choose their partners in India.

\footnotetext{
${ }^{4}$ Obscene acts and songs

(c) IARJSET 


\section{International Advanced Research Journal in Science, Engineering and Technology}

Vol. 8, Issue 8, August 2021

DOI: 10.17148/IARJSET.2021.8847

The main reasons for this honour killings are caste and status. It is hard to believe that there is no separate law for the prevention of this Honour Killings in India.

Sexual assault/rape is the most common crime against women in India. As per the NCRB reports, on an average of 88 cases are reporting daily in India. The worst part of this offence is committing it against the children. We amended Indian Penal Code and made the punishments more stringent for sexual assaults and we also have Protection of Children from Sexual Offences Act, 2012 to protect the children from sexual offences but the cases are on high and increasing day to day. The safety mechanism of the law enforcing departments shall be modified to monitor and ensure the safety of all the women. As per the GIWPS 5 in 2019, India ranked 133 out of 167 countries.

Domestic violence is harassing and abusing the women that may be physically, emotionally and financially. After enacting the "The Protection of Women from Domestic Violence Act, 2005, there is a geometrical growth in the reporting of the cases. During the Covid Lockdown in between the January and May, 2021, there are over 2300 complaints were filed in India which is highest in 20 years.

Dowry death is a death of married women who murdered or committed suicide by harassment of the husband and maternal family. Though the reported cases are small in number but there are many that go unreported. The Indian Penal Code, 1860 under Section 304B provides punishment for this offence, still the cases are increasing. The hard reality is that this dowry system is not limited to the rural areas but there are number of cases filing in the metropolitan cities also. The existing laws and punishments are not enough to end this system.

There is no peace for women at their old age in the form of mistreatment. Mistreatment in elderly age includes neglect, financial exploitation, emotional and physical abuse etc. in the old age, women need all possible ways of support financially and emotionally. But due to the unwanted behaviour of the younger generation, the elder people are not able to get the peace in their last days. To the welfare of the elder people, we enacted "Maintenance and Welfare of Parents and Senior Citizens Act, 2007. This Act provides all kinds of security to the aged but the government did not take any steps to promote and to create awareness regarding this Act.

\section{SUGGESTIONS:}

1. Establishing the special courts and speedy disposal of the cases.

2. The Government shall make the welfare schemes that are useful as per the changing dimensions of the problems of women.

3. Personality development and self-defence classes to be introduced from the school level to make the women strong and stable.

4. The government shall take steps to take counselling classes to the parents in every corner of the country to change their mindset to treat the gender

5. Without the proper education and implementation, the women favoured laws are of no use. The government shall take the responsibility to create awareness about the existing enactments.

6. The mobile applications and toll-free numbers shall be made and implemented on every offence.

7. The enactments shall be promoted through advertisements to reach all the people.

\footnotetext{
${ }^{5}$ Georgetown Uniiversity's Institute for Women Peace and Security 


\section{International Advanced Research Journal in Science, Engineering and Technology}

Vol. 8, Issue 8, August 2021

\section{DOI: 10.17148/IARJSET.2021.8847}

\section{CONCLUSION:}

It is noted that the life of women in India has undergone a drastic change from the past two decades. They stepped into each and every field and proved that they are not unable to do anything. But on the other hand, there are still a lot of women are living in the dark side. It is the duty of every citizen and the government to lit up their lives.

\section{REFERENCES}

1. Law against sexual harassment at workplace comes into effect. Times of India. Retrieved 14 December 2013.

2. Gangoli, Geetanjali (2007), "Sexual Harassment”, Indian Feminisms: Law, Patriarchies and Violence in India, Ashgate Publishing, Ltd., pp. 63-64, ISBN 978-0-7546-4604-4.

3. Criminal Law (Amendment) Act, 2013 (PDF), Government of India. Archived from the original (PDF) on 17 April 2013 . Retrieved 11 April 2013

4. Acid attacks against women in India on the rise: Survivors fight back, USA TODAY. Retrieved 2018-03-29.

5. Waheed, Abdul (February 2009). Dowry among Indian Muslims: Ideals and Practices.” Indian Journal of Gender Studies. 16 (1): $47-75$.

6. Anderson, Siwan (2007). "The Economics of Dowry and Brideprice." The Journal of Economic Perspectives.

7. Prohibition of Child Marriage Act to prevail over personal laws: HC. The Indian Express.

8. Census of India 2011: Child sex ratio drops to lowest since independence. The Economic Times, India.

9. $\quad$ Ethics: Honour crimes. BBC 1 January 1970 Retrieved 23 December 2013.

10. Meenakshi, J.V. (1 November 2016). "Trends and Patterns in the triple burden of malnutrition in India" (PDF). Agricultural Economics. 47 (S1): 115-134. doi: 10.1111/agec.12304. ISSN 1574-0862

11. Tisdell, Roy; Ghose (2001). “A critical note on UNDP’s gender inequality indices.” Journal of Contemporary Asia. 31 (3): $385-399$. Doi: $10.1080 / 00472330180000231$.

12. Rao, E Krishna (2006), "Role of Women in Agriculture: A Micro Level Study.” Journal of Global Economy, Vol 2.

13. National crime statistics (PDF). National Crime Records Bureau, India. 2013-01-16. Archived from the original (PDF) on 2014-06-20.

14. Elder Abuse Statistics - Statistics on Elderly Abuse over Time.

15. Sexual violence and rape in India. The Lancet, Vol 383, 8 March 2014

16. Antony Carla S.; Sumathi M.. "Maximum lifespan prediction of women from Modified Weibull Distribution". International Research Journal on Advanced Science Hub, 3, 3, 2021, 56-60. doi: 10.47392/irjash.2021.097

17. Nikhat Tabasum; B S Hugar. "Gender Differences Pertaining To Work-Life Balance". International Research Journal on Advanced Science Hub, 2, Special Issue ICARD 2020, 2020, 187-192. doi: 10.47392/irjash.2020.117 